\title{
From St. Petersburg to Dorpat and Back: On Academic Migration and Communication between Universities in the First Half of the 19th Century
}

The paper studies forms of academic interaction between the Universities of Dorpat and St. Petersburg such as student migration, targeted training of scientists for Russian universities at the Professors' Institute of Dorpat, book exchange, participation of representatives of two universities in joint commemorations and scientific expeditions. The University of Dorpat, included in the system of universities of the Russian Empire and in that of educational districts, served as a channel for the transfer of scientific personnel, as well as models of behavior adopted in the student society and going back to the traditions of German universities. Many graduates of the Dorpat University have made a brilliant scientific career in the capital of the Empire, among them P. I. Preiss, E. Lenz, and F. G. W. Struve. The medical faculty of the University of Dorpat acquired importance as an all-Russian training center for civilian and military doctors. The majority of the specialists who came to the University of Dorpat from the "interior" universities of the Empire were teachers of the Russian language.

\section{Introduction}

The history of interaction of universities in the Russian Empire is no less interesting than the study of the European university culture transfer to Russia. In this sense, the University of Dorpat was a cultural mediator between the universities of Europe and Russia. At the same time, the Dorpat University was included, until 1837, in the educational districts system of the Russian Empire, making possible active academic migration between universities and their subordinate schools. The university's geographical proximity to the St. Petersburg University and its educational district was important for the representatives of the University of Dorpat, which is why this direction of academic migration was preferred. At the same time, both universities were included in administrative, legislative, staffing and scientific respects in the centralized higher education system of the Russian Empire, which was under the jurisdiction of the Ministry 
of Public Education. This inclusion created conditions for multifaceted scientific and cultural interaction between the imperial universities.

Scientific contacts between the universities of the Russian Empire, especially at the initial stage of their existence, have been insufficiently studied. Contacts between the two universities have been occasionally discussed in the general works on the history of higher education in Russia (Petrov, 2003; Andreev, 2005), and also within the framework of the historiography of the universities of St. Petersburg (Grigoriev, 1870; Rozhdestvenskiy, 1919) and Dorpat (Petukhov, 1902; Istoriya Tartuskogo universiteta, 1982). At the same time, Estonian researchers have investigated the scientific relations of the University of Dorpat with the St. Petersburg Academy of Sciences (Müürsepp, 1978).

The scale, motivation, official registration and results of academic migration have been discussed only locally or have focused on specific persons or universities. The aim of our research is a full overview of academic migration between the University of Dorpat and that of St. Petersburg, including the period of existence of the Pedagogical Institute in St. Petersburg (1804-1819).

Our observations are based on the documents held in the funds of the St. Petersburg University, the Pedagogical Institute, the office of the curator of the Petersburg educational district in the Central State Historical Archive of St. Petersburg (Funds 13, 14, 139), departmental funds of the Department of Public Education (Fund 733), and the Office of Minister of Public Education (Fund 735) in the Russian State Historical Archive (RGIA). The materials of the university records are illustrated with the memoirs and correspondence of the university students.

\section{Academic contacts}

During the first half of the 19th century, the staff of professors at the University of Dorpat was sufficiently stable and more homogeneous in terms of ethnicity, as it included its own graduates or of those from German universities. Over time, the share of foreign professors declined. If in the first quarter of the 19 th century the share of graduate students of the Dorpat University among the professors was $27.1 \%$, then in $1826-1850$ it was already $48.5 \%$, and in 1851-1875 the percentage had grown to 56.2. The share of professors who had graduated from German universities decreased, respectively, from $60 \%$ in 
the 1810 s to $36 \%$ in the 1830 s-1840s, and $30 \%$ in the $1850 s-1860$ s (Istoriya Tartuskogo universiteta, 1982).

There were very few professors who came from Russia. The graduates of Russian universities occupied, first of all, the vacancies of teachers of Russian language and Russian law at the University of Dorpat, as well as those in grammar schools under Dorpat's educational district. Since 1807, organized distribution of the graduates of the metropolitan Pedagogical Institute took place, although not in large numbers. Only 2-3 students of the institute per graduation year agreed to go to Dorpat's educational district. According to the statistics for the first half of the 19th century, $58.5 \%$ of graduates of the Dorpat University stayed in the Baltic provinces, $37.7 \%$ went to serve in Russia, and 3.8\% left abroad (Pfaff, 1862, p. 20). Many graduates of the Dorpat University (e.g., V. S. Poroshin, E. V. Wrangel, F. K. Freytag, E. K. Hoffman, and E. Lenz) became talented scientists, members of the Academy of Sciences and professors at Russian universities, including St. Petersburg University.

The Professors' Institute played an important role in the training of scientists and professors of Russian universities, including St. Petersburg. The Institute operated for ten years (1828-1838) at the University of Dorpat. The experience of the Professors' Institute in Dorpat was supplemented with joint training of specialists in Russian law, who graduated from the universities of St. Petersburg and Dorpat (among the latter was, for example, P. Peterson).

Professors of both St. Petersburg and Dorpat universities actively participated in numerous expeditions carried out by the St. Petersburg Academy of Sciences. The Academy of Sciences maintained close ties with university observatories. Academicians F. G. W. Struve and G. F. Parrot, professors of the Dorpat University, and V. K. Vishnevsky and later E. Lenz, professors of St. Petersburg University, participated in the organization of the Pulkovo Observatory. According to the statute, this observatory was to coordinate the activities of all observatories in Russia, including the one in Dorpat.

The Empire-wide academic space was established through joint celebrations, such as the anniversary of the Dorpat University in 1852, attended by the representatives of both professors and students of St. Petersburg University. Professors Lenz and Hoffmann, for whom the University of Dorpat was their home university, were sent in this capacity. Thus, the personalized relationship between the two universities was emphasized (CGIA SPb, 1852). 
One of the forms of scientific cooperation between the two universities and the Academy of Sciences was exchange of specialized literature. Already in the 1800 s-1810s, the university record-keeping contains information about the transfer of dissertations and individual publications from one university to another, but this form of scientific cooperation remained episodic for a long time. Each university sought to replenish its library funds by buying or publishing new educational literature from abroad. Thus, in 1822, the book Entretiens sur la Physique, published by the professor of the Dorpat University G. F. Parrot, was purchased for the library of St. Petersburg University (CGIA SPb, 1822). Often the exchange of books, published at the expense of the treasury, took place in the form of book-swapping among the university professors.

\section{Student migration}

The main channel of the exchange of cultural traditions between the two universities was student migration. The student body of the University of Dorpat consisted almost entirely of the natives of the Baltic provinces, and the Polish, after the closing of the Warsaw and Vilnius universities. The number of Russian, as well as other foreign students in Dorpat was very small. The migration of the students from Great-Russian provinces to Dorpat was usually the result of the change of specialization to medicine- there was a prestigious medical faculty at the Dorpat University, with a lot of students, and there was no such a faculty at the St. Petersburg University.

Based on the archival documents, it is possible to restore some individual academic trajectories. For example, A. F. Middendorff was forced to enter the medical faculty of the University of Dorpat due to family circumstances rather than because of difficulties in studying medicine in the capital.

Another, but no less important, reason for the active migration of the youth of St. Petersburg to Dorpat was the geographical proximity of the two educational districts. For example, it was not so easy to go to Dorpat from Kazan. There were, however, exceptions. In 1855, P. D. Boborykin, a student of the law faculty at the Kazan University, who was fascinated by the natural sciences, decided to enter the medical faculty of the University of Dorpat: "I came already as a third-year student, with a serious, definite purpose, without any national or class fervor, to take advantage of the academic order that favorably distinguished Dorpat 
from all other universities in Russia" (Boborykin, 1965, p. 140). The memoirist wrote not only about the intellectual freedom that governed in the University of Dorpat, but also about the freedom in everyday life: "You can study, work in the laboratory, attend different courses, be at the source of German science, live cheaply and quietly" (Boborykin, 1965).

The presence of family and acquaintances in a small university town played a significant role for the newcomers. So, N. M. Yazykov chose to come to Dorpat because of his acquaintance with the professor of Russian language and literature of the Dorpat University, the writer A. F. Voeykov. Soon after his admission to the University of Dorpat, the student of the medical faculty V. I. Dal was well received at the home of Professor Johann Christian Moyer because he had recommendations from A. P. Zontag, and Field Marshal P. H. Wittgenstein.

As a rule, Russian students at Dorpat were the young gentry, keen on natural sciences or expected to enter the civil service. Traditionally attractive was also the department of Russian literature at the Dorpat University because of A. S. Kaisarov, A. F. Voeykov and V.M. Perevoshchikov.

The training of Russian students at Dorpat, as well as Ostsee Germans at the St. Petersburg University, was complicated due to the language barrier. Students who entered the University of Dorpat were expected to have a good command of the German language, in which teaching was conducted, and students of the medical faculty had to know Latin perfectly. Besides, medical students had to speak Russian well, because many of them entered the Russian service, including the military service, which took place in the interior provinces of the Empire.

In his circular of 1827, the Minister of Public Education A. S. Shishkov paid special attention to the fact that the "doctors who finished the course at the University of Dorpat had received knowledge in Russian" (Sbornik rasporyazheniy, 1866, pp. 581-583, 594-595). Due to the small number of Russian language teachers in grammar schools of the Dorpat educational district, the initial level of the knowledge of Russian language among the Ostsee youth was extremely low. For this reason, some of the Dorpat students who had moved to St. Petersburg were expelled for being unable to listen to lectures in Russian.

Student migration was often sanctioned by the university's administration. In 1838, two Polish students of the Dorpat University, Kempinsky and Kurnatovsky, were transferred to the St. Petersburg University to improve their command of Russian language. It was assumed that after graduation, the students would take 
up teaching vacancies at the Slutsk Gymnasium. Nevertheless, after a year of study, the Council decided to expel the students due to their poor knowledge of Russian.

Some incidents in the academic life at the Dorpat University created the need to update the university's legislation. The examples are the toughening of the rules for students after the students' "cases" in Dorpat in the 1810s, or the case of 1816 connected with the cancelling of the conferment of scientific degree for a fee, which existed at the Dorpat University, which resulted in the Proposition on Scientific Degrees in 1819.

Academic migration of students was regulated by the university law. If a student was expelled from a university for disciplinary offenses, he could not be admitted to any other university without obtaining a special permission from the minister. Universities regularly exchanged information about expelled students. For example, in 1821, the Board of the University of Dorpat reported to the Conference of St. Petersburg University about the exclusion of Georg von Wichmann and Alexander Belov due to their unreliability (CGIA SPb, 1841). The number of students expelled from the University of Dorpat for disciplinary offenses was higher than in other imperial universities. Thus, according to the Journal of the Ministry of Education, in 1835 eleven students were excluded from the University of Dorpat for "bad behavior", while only one student was expelled from St. Petersburg that year, and three students from Moscow and Kazan (Petrov, 2003, p. 376). This situation can be explained by the more liberal morals of the Dorpat's students and also by the traditional propensity to "riots", youth, and bravado, which distinguished the students of German universities.

The analysis of the documents of universities' record-keeping shows that despite the legal opportunities for student migration from one university to another, in practice such transfer without valid reasons and the consent of the university's administration was impossible for state students, and difficult for self-imposed ones. At the same time, the myth about free academic life in Dorpat was widespread among Russian students. In 1841, the students of the Kyiv University corresponded with the students of the Dorpat University, asking for information about the conditions of transfer and study. Young people were punished by the university's administration because of unauthorized contacts. (Zhukovskaya $\&$ Kazakova, 2018, p. 313) 


\section{Transfer of academic traditions}

The students who moved from one university to another carried with them the traditions and customs of the university in which they had studied before. The student subculture in Dorpat was significantly different from the one that was formed within the walls of the "interior" universities of the Russian Empire. At this university, legal literary student communities, various forms of selforganization, were initially permitted, and disciplinary rules were more lenient towards student pranks and entertainment.

At the beginning of 1835, the students of the University of Dorpat who had been expelled in 1833 for participation in the student society "Burschenschaft", were allowed to continue their studies in one of Russian universities, except Dorpat (Friedman, 2004, p. 59). Many of the expelled students chose St. Petersburg. In the university memoir, there are suggestions that the transfer of this group of students from Dorpat to the St. Petersburg University became one of the main reasons for the formation of student corporations in the capital's university in 1836 (Belov, 1880; Ozhe de Rankur, 1896). In the second half of the 1830s, student corporations of the type of national student societies were re-established at the University of St. Petersburg through the "academic" migrants from Dorpat: first a society of Baltic German students called "Baltika" was created, then the Russian corporation "Ruthenia". In addition, for the following 15 years there was a numerous community of Polish students at the St. Petersburg University (Kazakova, 2010). There were no such communities at that time either at the Moscow or Kazan universities, which is a vivid example of the transfer of corporate traditions during the academic exchange between Dorpat and St. Petersburg. The organization and transferring of the corporation was successfully carried out, despite police interest in the matter. A secret report of the Chief of Section III, Count A. F. Orlov to S. S. Uvarov mentioned that the student corporation "Baltika" had contacts with student communities in Dorpat (RGIA, 1836-1837).

Members of student societies both in Dorpat and St. Petersburg noted the positive aspects of student corporations. E. Degen, who studied at the University of Dorpat in the 1860s wrote: "While Russian students did not look through the rose-colored glasses at the orders of the old German regime, we appreciated the good aspects of the local culture" (Degen, 1902, p. 80). A strong supporter of the corporations was a graduate and future professor of the Dorpat University N. I. Pirogov. He considered the corporate structure of students as an important 
regulator of the "order and dean's activities". The distribution of the corporate forms from Dorpat to the St. Petersburg University had been put under control, and then suppressed by the government. Yet, the short-term experience of students' self-organization was conducive to the integration of Russian students, the weakening of class divisions, the formation of corporate identity, and anticipated the various forms of academic and public initiative of students born on the eve of the "great reforms" of the 1860s.

\section{Conclusion}

The exchange of scientific information and cultural traditions was constantly carried out between the University of Dorpat and that of St. Petersburg. Due to the migration of professors and students from one university to another, educational traditions as well as everyday practices were transferred, and it contributed to the development of professional standards and corporate ethics. However, the migration flows between Dorpat and St. Petersburg were not symmetrical. Thus, the number of graduates of Dorpat University who left for Russia was more than five times higher than the number of students who arrived to Dorpat from the Russian provinces. The results of migration of professors were also asymmetric. The ambitious young scientists of the Dorpat University, who had experience of studying in Europe (such as Lenz and Struve), moved to the capital of the Empire, made a fast academic career and became the first figures in their field of science. The close ties between the University of Dorpat and the St. Petersburg University testified to their inclusion in the unified scientific space not only of the Russian Empire, but also of Europe, as well as the absence of academic periphery in the pre-reform Russia.

\section{Ksenia Kazakova}

Kola Science Centre of the Russian Academy of Sciences

\section{Tatyana Zhukovskaya}

St. Petersburg State University 


\section{References}

Andreev, A. Iu. (2005), Russkiye studenty $v$ nemetskikh universitetakh XVIII-pervoy poloviny XIX $v$. [Russian students in the German universities of the 18th-the first half of the 19th century], Moscow: Znak.

Belov, I. D. (1880), Universitet i korporatsiya (otryvok iz vospominaniy) [University and corporation. A part of memories], Istoricheskii vestnik, vol. 1, no. 4, pp. 779-804.

Boborykin, P. D. (1965), Vospominaniya [Memoirs], vol. 1, Moscow: Izdatel'stvo khudozhestvennaya literatura.

CGIA SPb (1822), O pokupke knigi Entretiens sur la physique izdav. Prof. Derptskogo universiteta Parrotom, F. 139, op. 1, d. 3085, Central State Historical Archive of St.Petersburg.

CGIA SPb (1841), Po otnosheniiu g. rektora Derptskogo universiteta, ob iskliuchenii za durnoe povedenie studenta meditsiny A. Gene iz etogo universiteta, F. 14, op. 2, d. 344, Central State Historical Archive of St. Petersburg.

CGIA SPb (1852), O komandirovanii professorov Lentsa i Gofmana v Derptskii universitet dlia prisutstviia na 50-ti letnem iubilee O komandirovanii professora Nevolina $k$ redaktsii sistematicheskogo ispravleniia Voenno-ugolovnogo ustava, F. 139, op. 1, d. 5615, Central State Historical Archive of St. Petersburg.

Degen, E. (1902), Vospominaniya derptskogo studenta [Memoirs of Dorpat student], SPb.: Mir Bozhiy. pp. 71-105.

Friedman, R. (2004), Masculinity, Autocracy and the Russian University, 1804-1863, New York \& Berkeley: Palgrave Macmillan.

Grigoryev, V. V. (1870), Imperatorkiy S.- Peterburgskiy universitet v techeniye pervykh pyatidesyati let yego sushchestvovaniya [The Imperial St. Petersburg University during the first fifty years of its existence], St. Peterburg.

Istoriya Tartuskogo universiteta (1982), [History of the University of Tartu, 1632-1982]. Tallinn: Perioodika.

Kazakova, K. S. (2010), Studenchestvo Sankt-Peterburgskogo universiteta v pervoy polovine $X I X v$. [Students of Saint-Petersburg University in the first half of the 19th century] Candidate of Sciences thesis, St. Petersburg State University, Petrozavodsk.

Müürsepp, P. (1978), Peterburgskaya Akademiya nauk i Estoniya [St. Petersburg Academy of Sciences and Estonia], Tallinn: Valgus.

Ozhe de Rankur, N. F. (1896), 'V dvukh universitetakh: Vospominaniya. 1837-1843' [In two universities: Memoirs. 1837-1843], Russkaya Starina, vol. 86, no. 6, pp. 571-582.

Petrov, F. A. (2003), Rossiyskiye universitety v pervoy polovine XIX v.: formirovaniye sistemy universitetskogo obrazovaniya [Russian universities in the first half of the 19th century: forming a system of university education], vols. 1-4. Moscow: Moscow University Press. 
Petukhov, Ye. V. (1902), Imperatorkii Yurievskii, byvshii Derptskii universitet za sto let yego sushchestvovaniia [Imperial Yurievsky, a former the University of Dorpat for one hundred years of its existence], Yuriev.

Pfaff, G. (1862), Statisticheskiye materialy dlya opredeleniya obshchestvennogo polozheniya lits, poluchivshikh obrazovaniye $v$ Imperatorskom Derptskom universitete s 1802-1852 goda [Statistical materials for determining the social status of persons who received education at the Imperial University of Dorpat from 1802 to 1852], St. Petersburg.

RGIA (1841-1843), Delo o rassledovanii prichin, pobudivshikh studentov Kievskogo universiteta F.A. Ventskovskogo, D. Pil'chikova i P.E. Chuikevicha pisat'pis'ma studentam Gel'singforskogo i Derptskogo universitetov i ob ustanovlenii nabliudeniia za avtorami pisem. 2 marta 1841 g. - 7 avgusta 1843 g., F. 733, op. 69. d. 617. Russian State Historical Archive, St. Petersburg.

RGIA (1836-1837), O tainykh studencheskikh obshchestvakh, o volneniiakh studentov, ob areste ikh i uchrezhdenii nad nimi nadzora; o "o neblagonadezhnykh" uchiteliakh; o rassmotrenii tsenzuroi raznykh knig i periodicheskikh izdanii, Materialy Departamenta narodnogo prosveshcheniia za 1807-1824 g.g. po analogichnym voprosam, F. 735, op. 10. d. 175. Russian State Historical Archive, St. Petersburg.

Rozhdestvenskiy, S. V. (1919), S.-Peterburgskiy universitet v pervom stoletiye yego deyatelnosti. 1819-1919. Materialy po istorii S.- Peterburgskogo universiteta [St. Petersburg University in the first century of its activities. 1819-1919. Materials on the history of St. Petersburg University], Petrograd: 2-ya Gosudarstvennaya tip.

Sbornik rasporyazheniy (1866), Sbornik rasporyazheniy po Ministerstvu narodnogo prosveshcheniya [Collection of decrees on the Ministry of Public Education], vols. 1-2, St. Petersburg.

Zhukovskaya, T. N. \& Kazakova, K. S. (2018), Anima universitatis: Studenchestvo Peterburgskogo universiteta v pervoy polovine XIX veka [Anima universitatis: Students of Petersburg University in the first half of the 19th century], Moscow. 